\title{
Ethnoveterinary Survey of Medicinal Plants Used for Treatment of Animal Diseases in Ambo District of Oromia Regional State of Ethiopia
}

\author{
Mulugeta Berhanu, ${ }^{1}$ Tarekegn Tintagu, ${ }^{1}$ Selamawit Fentahun, ${ }^{1}$ and Mirutse Giday iD $^{2}$ \\ ${ }^{1}$ School of Veterinary Medicine, Wollo University, P.O. Box 1145, Dessie, Ethiopia \\ ${ }^{2}$ Aklilu Lemma Institute of Pathobiology, Addis Ababa University, P.O. Box 1176, Addis Ababa, Ethiopia \\ Correspondence should be addressed to Mirutse Giday; mirutse.giday@aau.edu.et
}

Received 20 August 2020; Revised 7 December 2020; Accepted 10 December 2020; Published 16 December 2020

Academic Editor: Adolfo Andrade-Cetto

Copyright (c) 2020 Mulugeta Berhanu et al. This is an open access article distributed under the Creative Commons Attribution License, which permits unrestricted use, distribution, and reproduction in any medium, provided the original work is properly cited.

\begin{abstract}
Traditional knowledge on the use of medicinal plants is in danger of extinction because of different changes taking place all over the world including Ethiopia, and thus, there is a need for its immediate documentation for the purpose of conservation, sustainable utilization, and development. Thus, an ethnobotanical study was conducted in Ambo District, Oromia Regional State of Ethiopia, to document and analyze local knowledge on medicinal plants used for the treatment of animal diseases. Data were collected between November 2017 and April 2018 mainly through semi-interviews conducted with purposively selected informants. Data collected mainly included demographic information of respondents, local names of medicinal plants, plant parts used, preparation methods, mode of applications, diseases treated, and habit and habitat of the reported plants. Based on data obtained through interviews, informant consensus factor (ICF) values were computed. A total of 55 medicinal plants used to manage livestock ailment were reported by informants in the Ambo District. Herbs were commonly used in the preparation of remedies. Leaf was the most frequently utilized plant part accounting for $49.1 \%$ of the total reported medicinal plants. The majority $(69.0 \%)$ of the medicinal plants used in the study district were uncultivated ones mainly harvested from edges of forests and bushlands, roadsides, riverbanks, and grasslands. High ICF values were obtained for ophthalmological (0.82), dermatological (0.79), febrile (0.77), and gastrointestinal ailments (0.77). The current study shows that there is still rich traditional knowledge on the use of plants to control various animal diseases in the study district. However, such a claim needs to be scientifically verified with priority given to medicinal plants used in the treatment of ailment categories with high ICF values as such plants are considered to be good candidates for further pharmacological evaluation.
\end{abstract}

\section{Introduction}

In Ethiopia, traditional medicine, in general, and medicinal plants, in particular, are still playing a significant role in solving livestock health problems [1]. Ethnoveterinary systems of treatment are still widely used even in areas where modern veterinary services have been introduced many years ago [2]. However, despite the significant role that has been played by medicinal plants in treating livestock ailments in both settled and pastoralist areas in Ethiopia, very limited attempts have been done to explore, document, evaluate and develop, and promote them for their wider uses in the country [3]. Survey to document and analyze the traditional use of medicinal plants is an urgent matter as both plant materials and the associated traditional knowledge are currently being lost at an alarming rate due to various factors mainly including environmental degradation, deforestation, and acculturation [4-6].

There are several ethnoveterinary surveys carried out in Oromia Region of Ethiopia to which also the Ambo District belongs [7-13]. However, a literature survey shows that there was no proper ethnoveterinary study so far conducted in Ambo District to document the use of medicinal plants in managing livestock ailments. Some personal communications 
indicate the wide practice of using medicinal plants to control different types of animal health problems in the study area. Therefore, the purpose of this study was to document and analyze medicinal plants used to treat livestock diseases in Ambo District of the Oromia Region of Ethiopia.

\section{Materials and Methods}

2.1. Description of Study Area. Ambo District administratively belongs to West Shoa Zone, Oromia Regional State of Ethiopia. Ambo town is an administrative centre for both Ambo District and West Shoa Zone. The town is located at a distance of $114 \mathrm{~km}$ west of Addis Ababa within latitudes of $8^{\circ} 59^{\prime}$ and $8.983^{\circ} \mathrm{N}$ and longitudes of $37^{\circ} 51^{\prime}$ and $37.85^{\circ} \mathrm{E}$ and has an elevation of 2101 meters above sea level [14]. Ambo town has an annual rainfall of $1007.3 \mathrm{~mm}$ and mean minimum, mean maximum, and mean average monthly temperatures of $9.96^{\circ} \mathrm{C}, 19.82^{\circ} \mathrm{C}$, and $14.89^{\circ} \mathrm{C}$, respectively [15]. According to Tamiru et al. [14], the agroecology of Ambo District consists of highland (23\%), midland (60\%), and lowland (17\%). The District is divided into 34 administrative kebeles; kebele is the smallest unit of administration in Ethiopia.

The livelihood of people in the district is largely dependent on agriculture mainly involving crop production and animal rearing [16]. The district has a livestock population of 145371 cattle, 50152 sheep, 27026 goats, 105794 chickens, 9088 horses, 2914 donkeys, and 256 mules [14]. Liver fluke, pasteurellosis, blackleg, epizootic lymphangitis, African horse sickness, trypanosomiasis, ascariasis, leech worm infestation, gastrointestinal parasites infection, lumpy skin disease, anthrax, and foot and mouth disease are the commonly occurring diseases in the study district, of which anthrax, blackleg, and foot and mouth disease are considered the most serious ones [17]. There are 13 veterinary clinics in the study district and a total of 21 veterinary professionals, of which four are DVM holders, three are BVSc holders and 14 are animal health attendants (Ambo District Agriculture Office, unpublished data, 2018).

\subsection{Informants Sampling and Data Collection. A total of 55} knowledgeable informants with ages ranging from 35 to 71 years were purposively selected from the study district with the support of the Ambo District Administration Office and respected local elders. Of these, 31 were males and 14 were females. Ethnoveterinary data were collected from November 2017 to April 2018 through individual semistructured interviews that were held with the selected informants. In the interviews conducted in the Oromo language, the widely spoken language in the study area, data on sociodemography of the informant, local names of medicinal plants used in ethnoveterinary practices, parts used, preparation methods, mode of applications, and diseases treated were collected. Data related to habitats of threats to medicinal plants were also gathered during interviews. Prior informed consent was obtained from all informants who participated in the study. Voucher specimens of medicinal plants reported during interviews were collected, properly pressed, dried, and identified by their scientific names by a botanist at Aklilu Lemma Institute of Pathobiology (ALIPB), Addis Ababa University, and were deposited at the miniherbarium of the Medicinal Plants Unit at ALIPB.

2.3. Data Analysis. Ethnobotanical data on the local use of medicinal plants were entered into Microsoft Excel spreadsheets, analyzed using SPSS version 20 software, and summarized using appropriate descriptive statistical methods. Informant consensus factor (ICF) values were also calculated to determine the level of agreement of informants on the reported medicinal plants for the treatment of a given major ailment category using the formula $\mathrm{ICF}=($ nur $-\mathrm{nt}) /($ nur -1$)$, where nur $=$ number of informant citations for a particular ailment category and $\mathrm{nt}=$ number of medicinal plants used for the same ailment category with ICF values ranging between 0.00 and 1.00 [18]. ICF helps in the identification of medicinal plants with relatively higher informants' agreement in choosing them in the treatment of a given ailment category [19]. Grouping the specific ailments into major ailment categories was made with the assistance of a veterinarian at ALIPB, Addis Ababa University, following the approach of Heinrich et al. [18]. ICF values were calculated for major disease categories against which at least five informant use reports were recorded following the approach of Lautenschläger et al. [20].

\section{Results}

3.1. Medicinal Plants Used and Ailments Managed. The current study documented 55 medicinal plant species that were used in Ambo District to manage several livestock ailments (Table 1). The plants were distributed across 36 families and 53 genera. Of the total medicinal plants reported, relatively higher numbers of medicinal plants belonged to the families Euphorbiaceae and Lamiaceae, each contributing five species. The families Fabaceae and Solanaceae contributed four medicinal plants each, and the families Acanthaceae, Asteraceae, Malvaceae, Ranunculaceae, and Rubiaceae contributed two medicinal plants each. The rest of the families contributed one medicinal plant each. Herbs were the most commonly used ones in the preparation of remedies in the study district accounting for 32 species (58.2\%), followed by shrubs (17 species; $30.9 \%$ ) and trees (6 species; 10.9\%). The highest number of medicinal plants (29 species) was used to manage gastrointestinal complaints including bloat, colic, endoparasites infections, and diarrhea which largely affect cattle, sheep, and goats. A good number of medicinal plants were also used to treat febrile illness (9 species) and eye infection (5 species).

3.2. Part Used, Methods of Preparation, and Route of Administration. Leaf was the most commonly used plant part in the preparation of remedies accounting for $49.1 \%$ of 


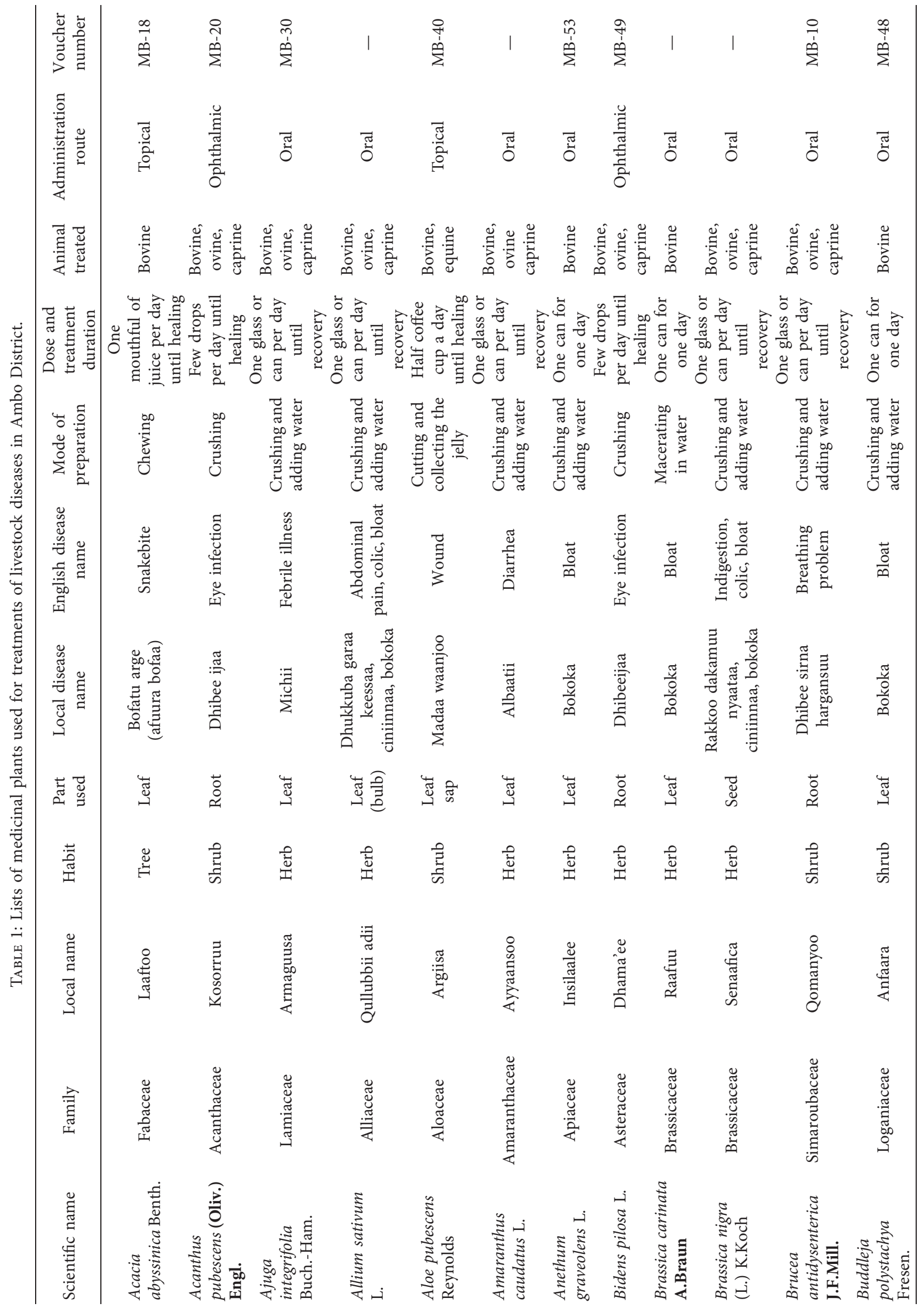




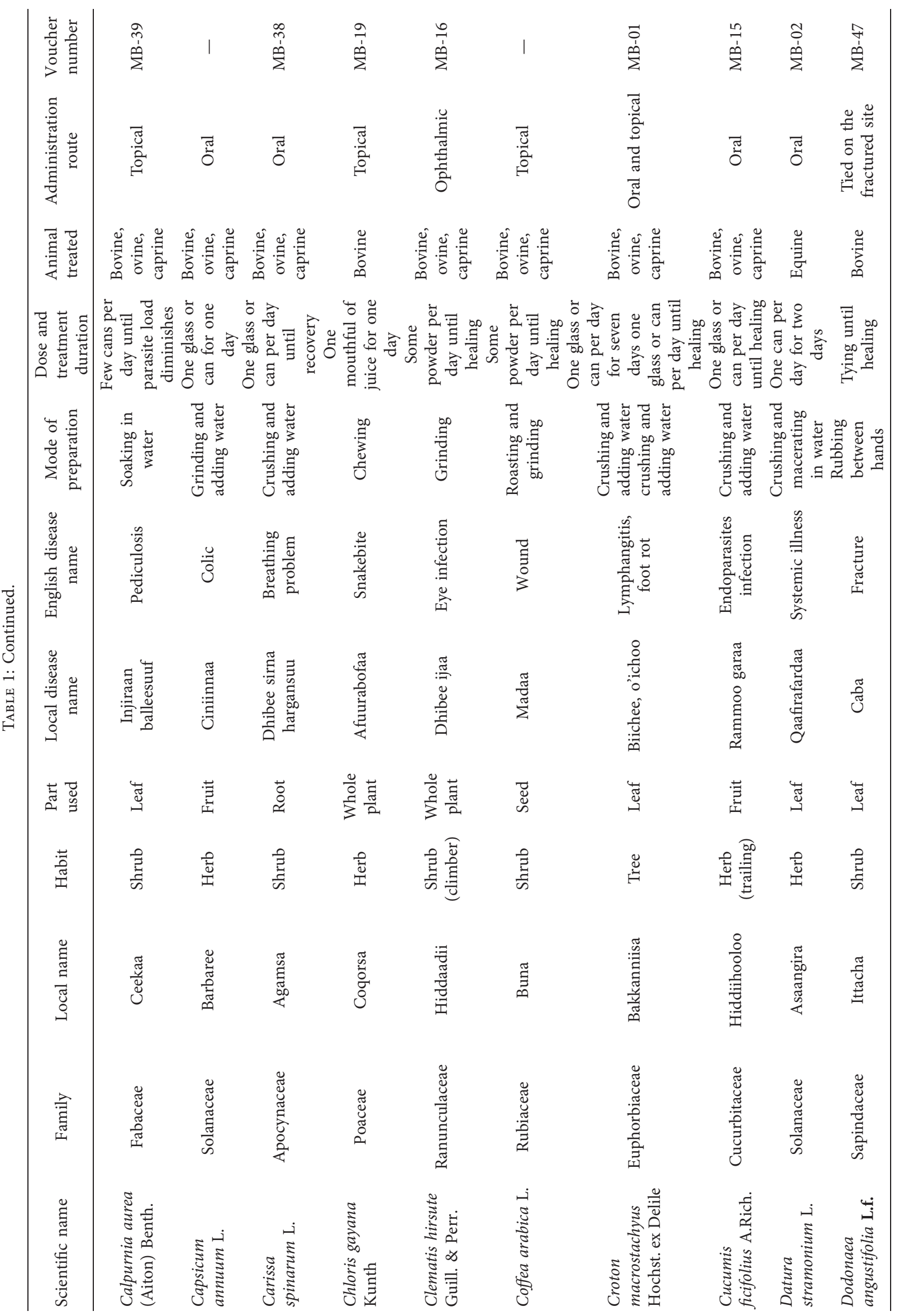




\begin{tabular}{|c|c|c|c|c|c|c|c|c|c|c|}
\hline 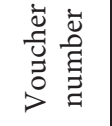 & $\begin{array}{l}\hat{m} \\
\dot{a}\end{array}$ & $\begin{array}{l}\tilde{\imath} \\
\ddot{n}\end{array}$ & $\begin{array}{l}\hat{\vec{n}} \\
\overrightarrow{\dot{a}}\end{array}$ & 1 & $\begin{array}{l}\stackrel{\mathscr{1}}{2} \\
\dot{\mathfrak{z}}\end{array}$ & 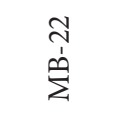 & $\stackrel{\sim}{\stackrel{1}{a}}$ & $\begin{array}{l}\overrightarrow{1} \\
\dot{n}\end{array}$ & $\begin{array}{l}\tilde{h} \\
\stackrel{n}{n}\end{array}$ & 1 \\
\hline 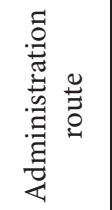 & 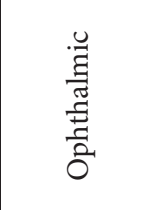 & 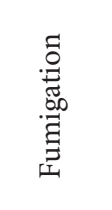 & 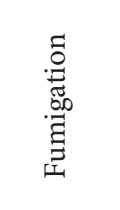 & 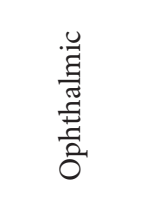 & స్త్ర & 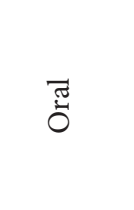 & 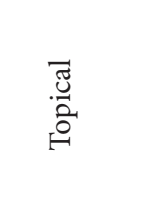 & $\overline{\widetilde{J}}$ & రే & 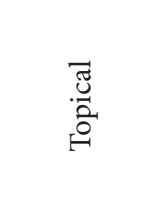 \\
\hline 息莺 & 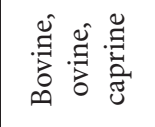 & 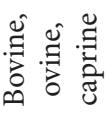 & 息 & 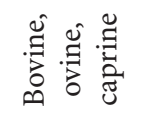 & 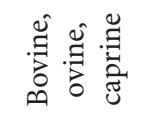 & 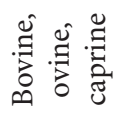 & 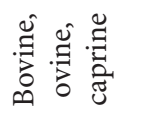 & 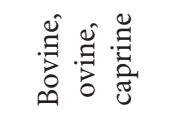 & 节泀芯 & 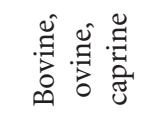 \\
\hline 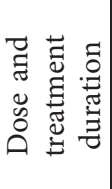 & 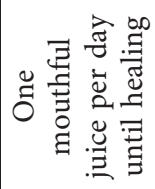 & 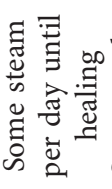 & 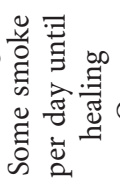 & 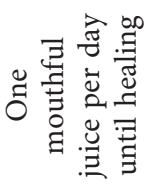 & 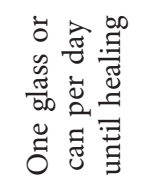 & 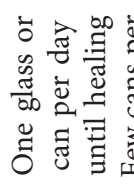 & 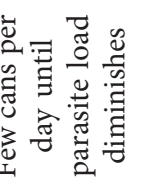 & 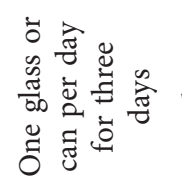 & 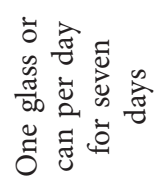 & 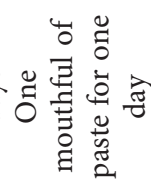 \\
\hline 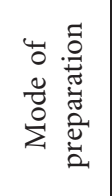 & 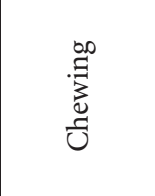 & 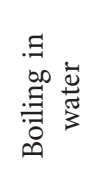 & 号 & 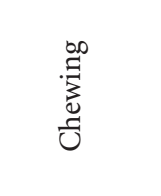 & 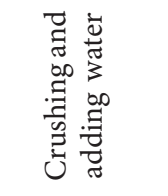 & 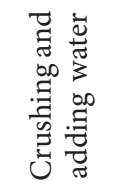 & 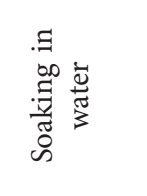 & 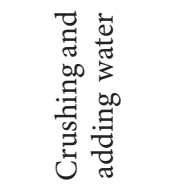 & 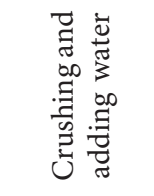 & $\begin{array}{l}\text { 离 } \\
\text { 竎 } \\
\text { J }\end{array}$ \\
\hline 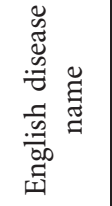 & 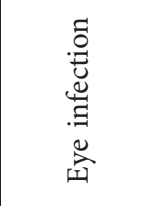 & 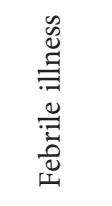 & 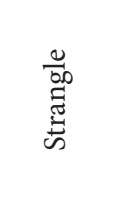 & 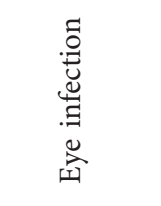 & 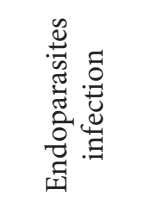 & 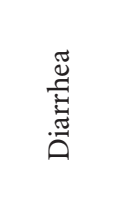 & 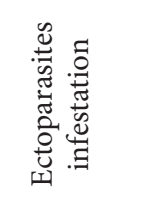 & $\frac{\mathscr{\vartheta}}{\pi}$ & 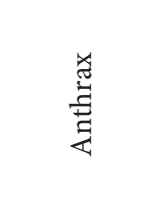 & 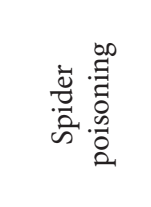 \\
\hline 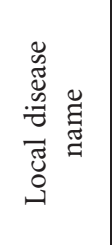 & 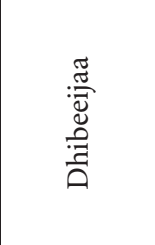 & $\begin{array}{l}:=7 \\
: \frac{\pi}{\breve{z}} \\
\end{array}$ & $\stackrel{8}{\stackrel{0}{3}}$ & 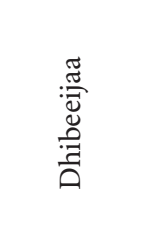 & 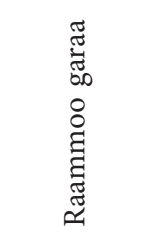 & 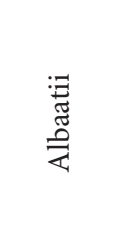 & 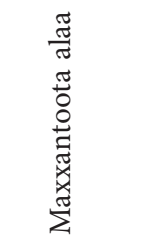 & 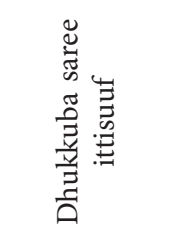 & 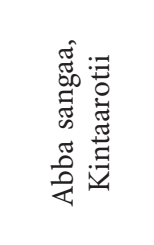 & 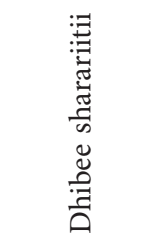 \\
\hline 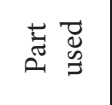 & $\begin{array}{l}\frac{0}{0} \vec{z} \\
\frac{\pi}{3}\end{array}$ & $\stackrel{\breve{J ~}}{\leftrightarrows}$ & 表 & 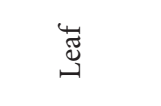 & 莺 & $\begin{array}{l}\vec{\circ} \\
\stackrel{0}{2}\end{array}$ & $\overleftrightarrow{\widetilde{\Xi}}$ & 岕 & $\begin{array}{l}\vec{\circ} \\
\stackrel{\circ}{a}\end{array}$ & $\begin{array}{l}\bar{\Xi} \\
\ddot{心}\end{array}$ \\
\hline 莡 & $\begin{array}{l}\text { 离 } \\
\text {. }\end{array}$ & 苂 & $\begin{array}{l}\text { 离 } \\
\text { 至 }\end{array}$ & 节 & 节 & $\begin{array}{l}\text { 离 } \\
\text {. }\end{array}$ & 节 & 竓 & 离 & $\begin{array}{l}\text { 离 } \\
\text { 芴 }\end{array}$ \\
\hline 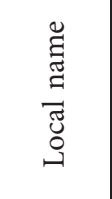 & 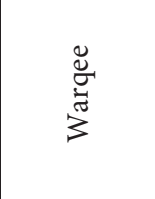 & 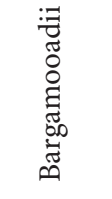 & 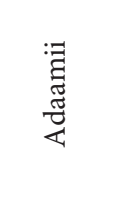 & $\begin{array}{l}\frac{\pi}{\Xi} \\
\text { है } \\
\text { है }\end{array}$ & 离 & 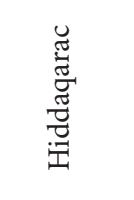 & 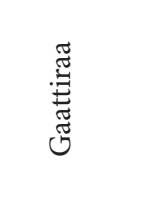 & 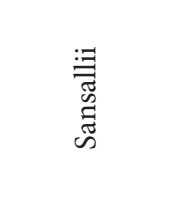 & 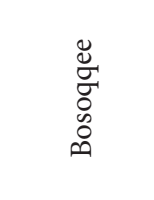 & 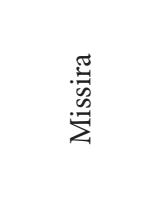 \\
\hline 氶 & 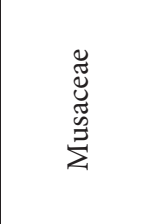 & 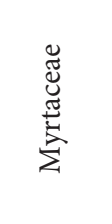 & 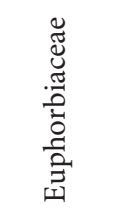 & 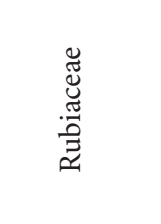 & 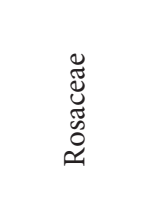 & 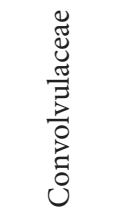 & 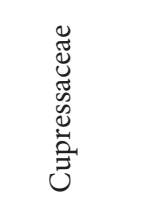 & 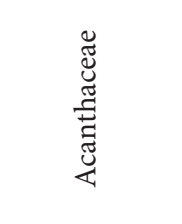 & 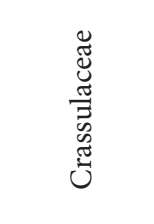 & 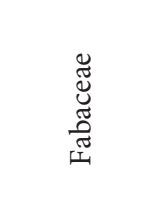 \\
\hline 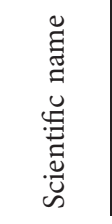 & 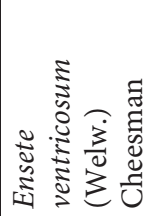 & 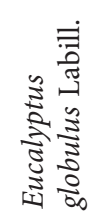 & 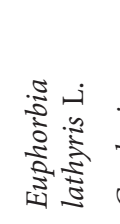 & 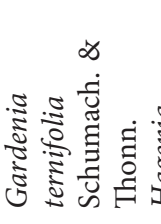 & 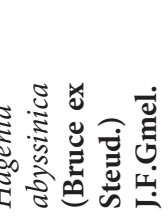 & 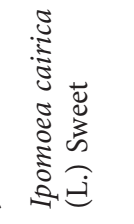 & 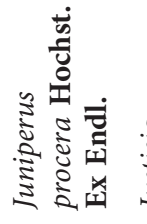 & 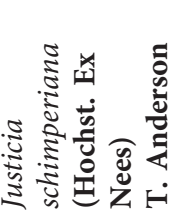 & 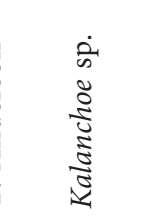 & 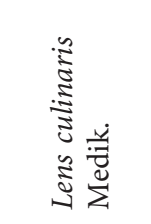 \\
\hline
\end{tabular}




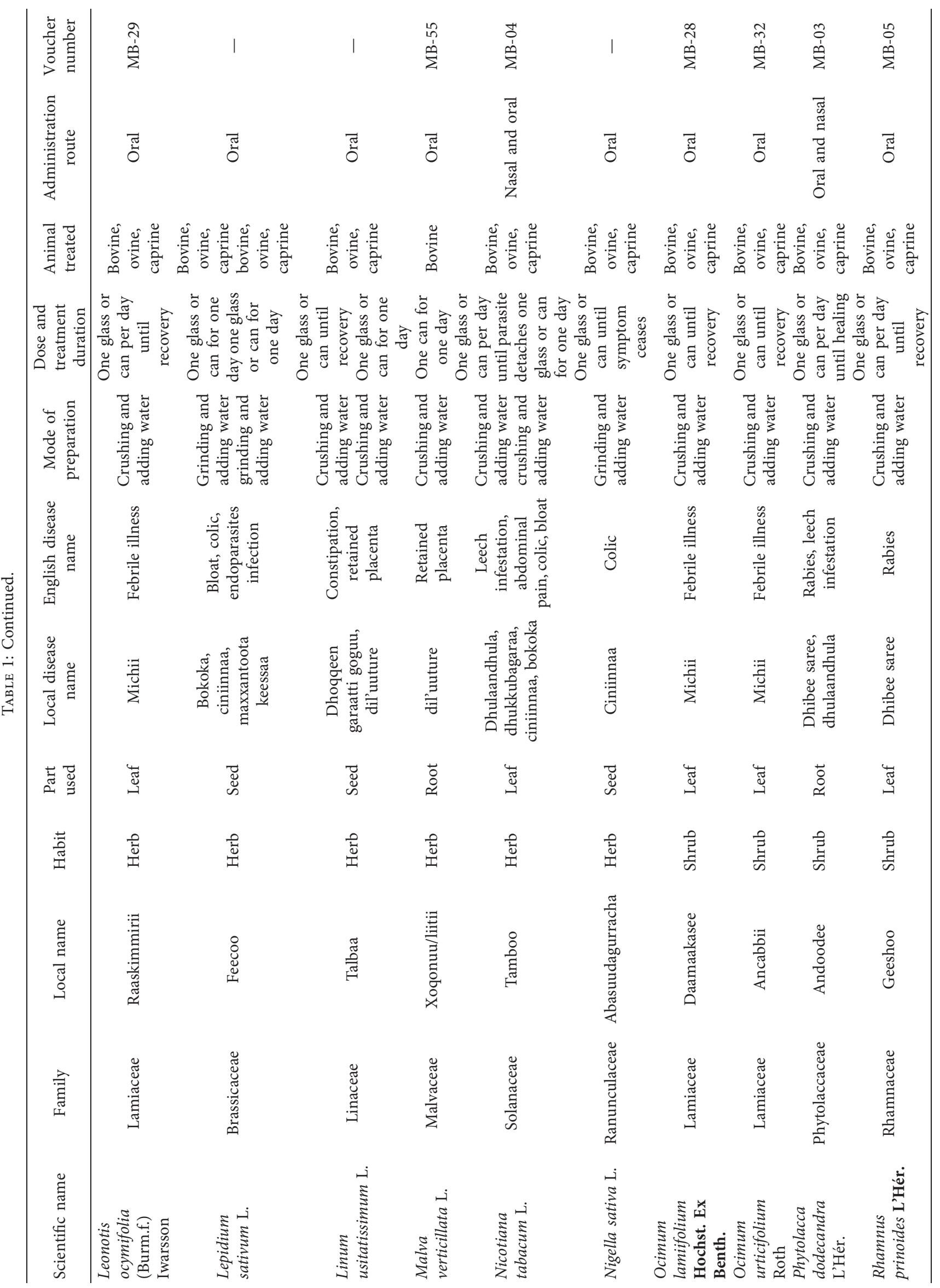




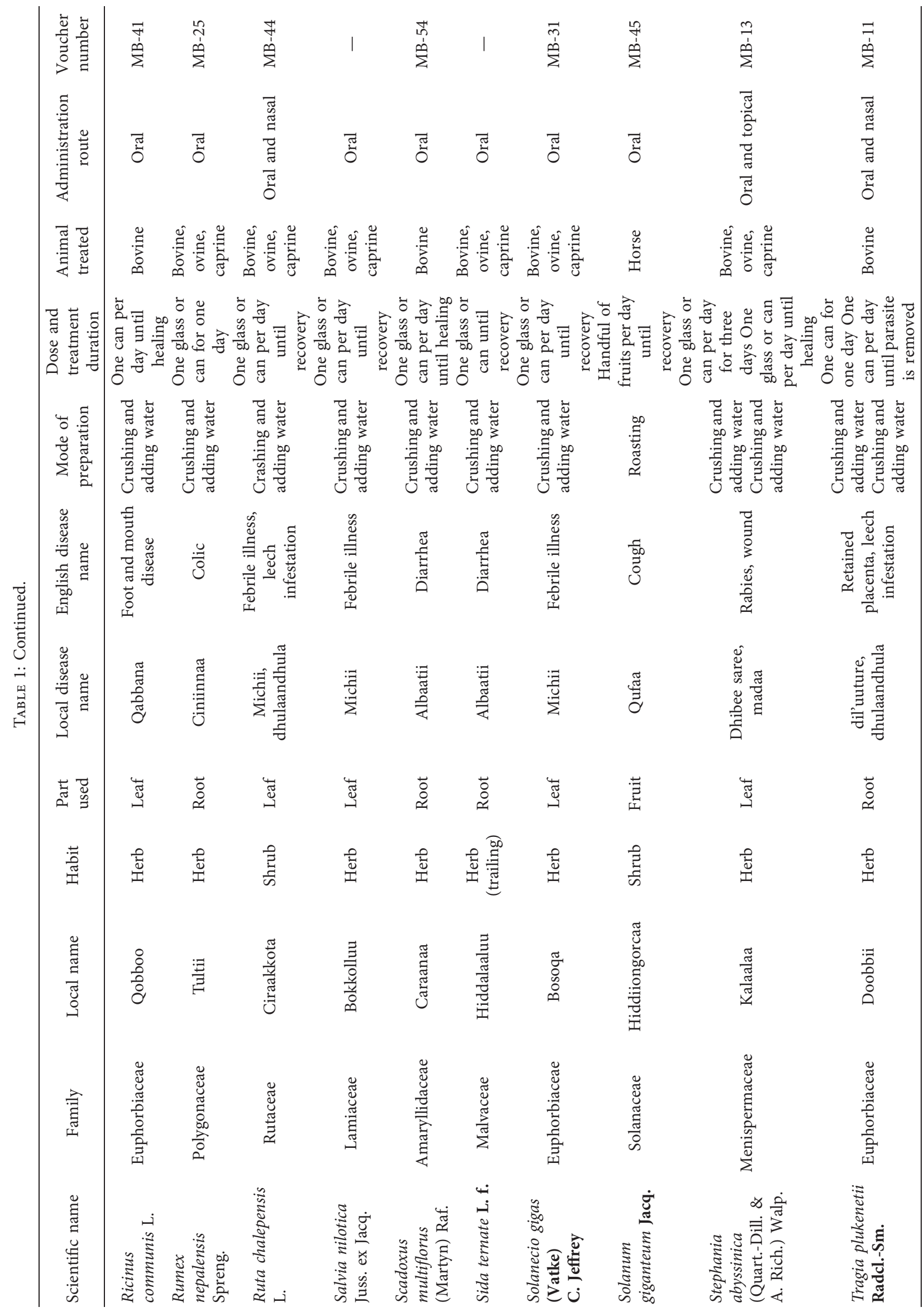




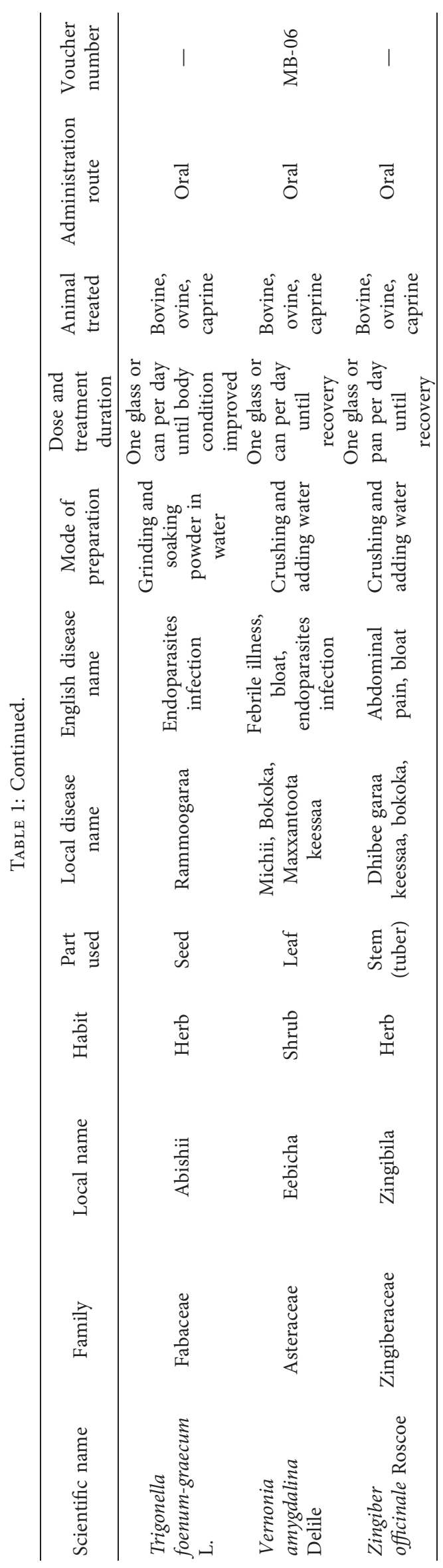


the total reported medicinal plants, followed by those used for their root $(21.8 \%)$ and seed $(12.7 \%)$ parts (Figure 1$)$.

The result shows that most $(62.7 \%)$ remedies in the study district were prepared by crushing (Figure 2 ). There was very little practice of storing plant materials for future use in the study district; plant parts were mostly harvested for their immediate uses. As a result, the majority (72.1\%) of remedies were prepared from fresh plant materials. Only a few were prepared from dry (22.9\%) or dry or fresh (5.0\%) materials. Most (85.3\%) remedies were processed with the addition of water, while few $(14.7 \%)$ were prepared without the use of any diluent. The majority $(58.2 \%)$ of medicinal plant preparations were revealed to be administered orally, and some were administered dermally (19.5\%), taken nasally $(18.8 \%)$, or applied through the eyes $(3.5 \%)$.

3.3. Informant Consensus Factor. ICF values were calculated for major disease categories against which at least five informant use reports were recorded. Accordingly, ophthalmological (0.82), dermatological (0.79), febrile (0.77), and gastrointestinal (0.77) ailments were found to be the major disease categories that scored high ICF values in the study district (Table 2).

3.4. Habitat. The majority (69.0\%) of the claimed medicinal plants in the study district were found to be uncultivated ones mainly harvested from edges of forests and bushlands, roadsides, riverbanks, and grasslands. Few of the uncultivated ones were weeds growing in cultivated fields and home gardens. Some $(31.0 \%)$ of the reported medicinal plants were cultivated in home gardens but primarily for other purposes. Only Ocimum lamiifolium, Ocimum urticifolium, and Lepidium sativum were cultivated in the home garden primarily for their medicinal uses.

3.5. Comparison of Knowledge of Medicinal Plants between Different Social Groups. Analysis of data collected revealed a significant difference $(p<0.05)$ in medicinal plant knowledge between the older ( $\geq 46$ years of age) and the younger ( $<46$ years of age) people. The mean number of medicinal plants reported by the older people was 5.2 while that reported by the younger people was 3.0. The study further showed a significant difference $(p<0.05)$ between males and females in the mean number of medicinal plants reported; 4.5 and 3.2 were the mean numbers of medicinal plants reported by males and females, respectively. However, there was no significant difference $(p>0.05)$, in the mean number of medicinal plants reported, between illiterate (those who cannot read and write) (4.3) and literate (those who can read and write) (4.1) people.

\section{Discussion}

4.1. Medicinal Plants Used and Ailments Managed. The number of medicinal plants (55 species) documented from Ambo District that was used to manage several livestock ailments is comparable to a figure reported by a study conducted in Midakegn District of West Shoa Zone, to which also Ambo District belongs, which revealed the use of 60 medicinal plants to treat different livestock ailments [12]. On the other hand, the number of medicinal plants reported by the current study is much higher as compared to figures reported by studies conducted in different districts of three neighboring zones of the Oromia Region, namely, Horro Guduru, Jimma, and East Wollega zones [7, 8, 21]. Twentyeight medicinal plants were documented from East Wollega Zone [21]; 25 medicinal plants were documented from Horro Gudurru [8]; and 21, 20, 19, and 14 medicinal plants were recorded from Manna, Dedo, Kersa, and Seka Chekorsa districts of the Jimma Zone, respectively [7]. The fact that a higher number of medicinal plants were reported from the study district as compared to some neighboring districts or zones could be attributed to the rich livestock population in the district as reported in Tamiru et al. [14]. The fact that Euphorbiaceae and Lamiaceae contributed a higher number of plants to the medicinal plants flora of the study district may be related to their respective sizes in terms of the number of species each comprises in the flora of Ethiopia. Euphorbiaceae and Lamiaceae are among the largest families in the Flora of Ethiopia and Eritrea containing 209 and 184 species, respectively $[22,23]$. The relative richness of the two families in medicinal plants may also be related to their richness in some active principles. The common use of herbaceous plants in the study district in the preparation of remedies could be attributed to the better abundance of the same as compared to other life forms as was also observed by the investigators of the study during their visits to the study area. The common use of herbs was also reported by other ethnoveterinary studies carried out in Midakegn District of West Shewa Zone [12] and some districts of Horro Guduru [8] and East Wollega [21] zones. The use of a high number of medicinal plants for the treatment of gastrointestinal complaints could be an indication of a high prevalence of this ailment category in the study district. According to Bacha and Taboge [17], gastrointestinal ailments are among the commonly occurring diseases in the study district.

4.2. Part Used, Methods of Preparation, and Route of Administration. Leaf was the most commonly used plant part in the preparation of remedies, which is in agreement with studies conducted in other parts of the country $[8,12,21]$. The wider use of leaves may be related to the fact it is much easier and faster to prepare remedies from such plant part. Most remedies in the study district were prepared by crushing, a method which is also commonly applied in the preparation of remedies elsewhere in the country $[1,13,24-26]$. The common use of crushing in the preparation of remedies may be related to its easiness. Most remedies in the study district are prepared from fresh plants materials and other studies conducted in different parts of Ethiopia [8, 10, 13, 26, 27] also reported the common use of fresh materials. The wider use of fresh materials in remedy preparation could indicate the availability of most of the needed plant parts in the vicinity any season of the year. The common use of water as a diluent in processing remedies in the study district may be related to its property in dissolving many 


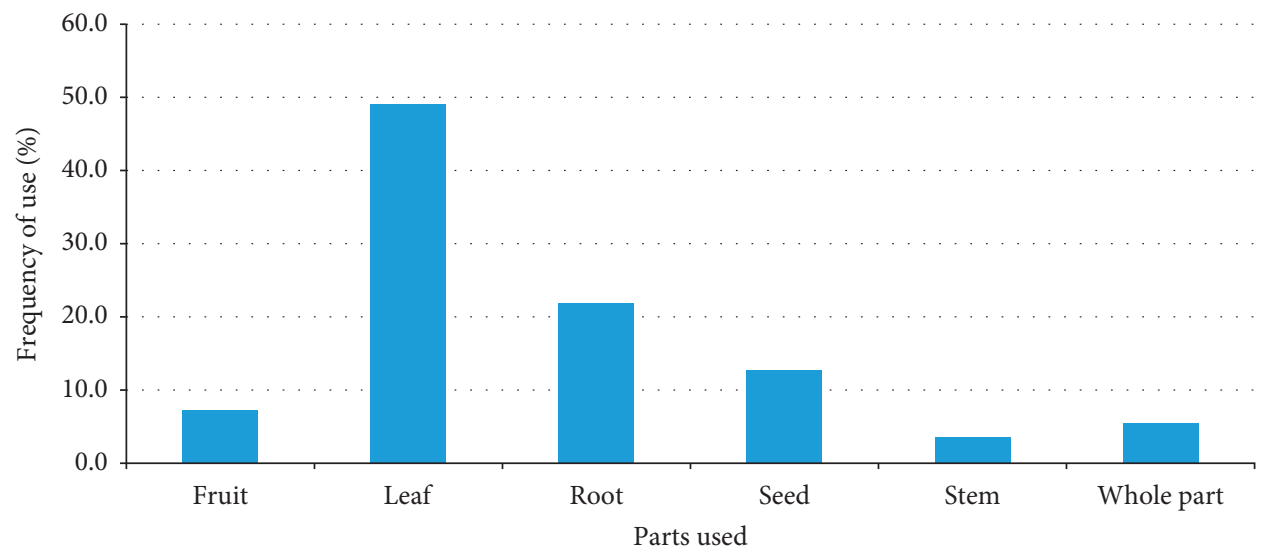

FIGURE 1: Frequency of plant parts used in the preparation of remedies in Ambo District.

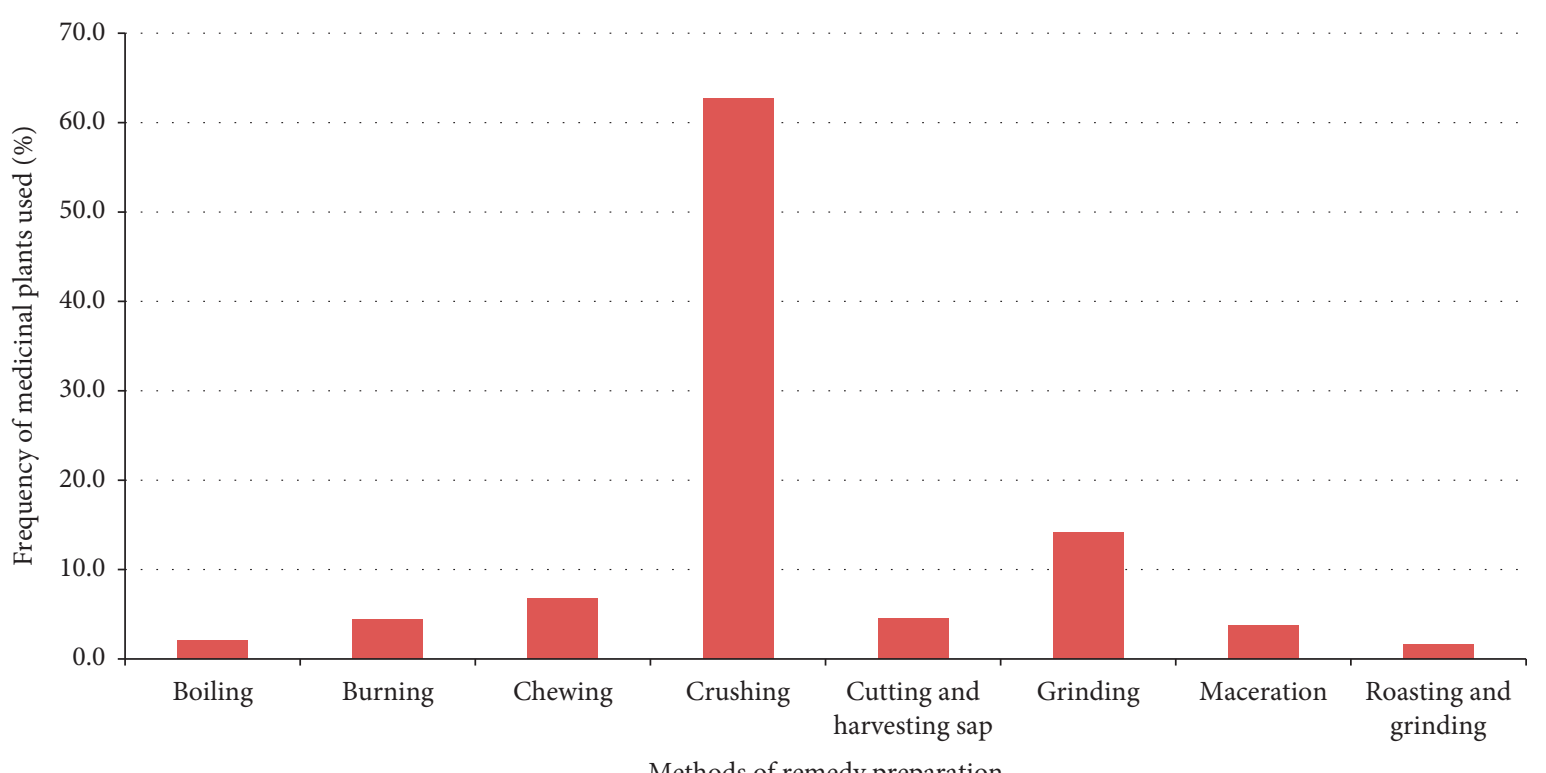

FIgURE 2: Frequency distribution of the different remedy preparation methods in Ambo District.

TAвLE 2: Informant consensus factor calculated for major disease categories in Ambo District.

\begin{tabular}{lccr}
\hline Category of the disease & Numbers of plant species & Number of informant citations & ICF \\
\hline Ophthalmological & 4 & 18 & 0.82 \\
Dermatological & 10 & 43 & 0.79 \\
Febrile & 10 & 78 & 0.77 \\
Gastrointestinal & 19 & 12 & 0.77 \\
Snake and spider poisoning & 4 & 18 & 0.73 \\
Nervous system & 6 & 12 & 0.71 \\
Respiratory system & 5 & 5 & 0.64 \\
Reproductive system & 3 & 6 & 0.50 \\
Others/unclassified & 5 & & 0.20 \\
\hline
\end{tabular}

active compounds. The fact that most remedies were administered orally could be attributed to the common occurrence of gastrointestinal tract ailments in the study district. A study reveals that gastrointestinal ailments are among the top animal health problems in the study district [17].
4.3. Informant Consensus Factor. Ophthalmological, dermatological, febrile, and gastrointestinal ailments were the major disease categories that scored high ICF values in the study district and medicinal plants used against such ailments categories could be considered as good candidates for 
further pharmacological evaluation as they are expected to exhibit better potency as compared with those that are used to treat ailment categories with low ICF values [18].

4.4. Habitat. The majority of the claimed medicinal plants in the study district were found to be uncultivated ones, which is in agreement with reports of other studies conducted elsewhere in the country $[8,13,26,28]$. The fact that the majority of medicinal plants were harvested from the wild indicates a serious threat to the same amid ongoing deforestation and habitat destruction that are taking place in the country.

4.5. Comparison of Knowledge of Medicinal Plants between Different Social Groups. The fact that older people in the study district had better knowledge of medicinal plants as compared with the younger ones may indicate the problem medicinal plant knowledge transfer, across generations, is facing, which could be related to lack of interest by the younger generation to practice traditional medicine due to acculturation. Other studies conducted elsewhere in different parts of the country also demonstrated that older people have a better knowledge of medicinal plants as compared with younger ones $[29,30]$. The reason why males had better knowledge of medicinal plants as compared with females could be related to the fact that, in Ethiopia, traditional medical practice is dominated by men which is reflected in the choice of knowledgeable people to transfer their knowledge along the male line [31]. There was no difference in knowledge of medicinal plants between illiterate people and literate ones as was also reported by a study conducted in Ankober District of Amhara Region of Ethiopia [30].

\section{Conclusion}

The present study revealed rich knowledge on the use of medicinal plants for the treatment of various livestock ailments in Ambo District. It was found out that the highest number of medicinal plants was used to manage gastrointestinal complaints, an indication of a high prevalence of this ailment category in the area. Most remedies in the study district were prepared by crushing leaves and this may be related to their easiness. The majority of the claimed medicinal plants were found to be harvested from the wild and this indicates their serious threat amid ongoing deforestation and habitat destruction taking place in the country. The highest ICF value was obtained for ophthalmological problems. Thus, priority for evaluation should be given to medicinal plants used in the treatment of ophthalmological problems as medicinal plants used in the treatment of ailments with high ICF values are considered to be good candidates for further pharmacological studies.

\section{Data Availability}

Ethnoveterinary data were stored in a computer available at Aklilu Lemma Institute of Pathobiology (ALIPB). Readers may request ALIPB for permission to get access to the data.

\section{Disclosure}

This manuscript is available online as a preprint and can be accessed through the link https://www.researchsquare.com/ article/rs-5193/v1. The role of the office is to support academic staff and students to conduct problem-solving research and publish their findings.

\section{Conflicts of Interest}

The authors declare that they have no conflicts of interest.

\section{Acknowledgments}

The authors are very grateful to the informants in Ambo District for their unreserved willingness to share their traditional knowledge with them on the use of plants for ethnoveterinary purposes. The authors thank Ambo District Administration Office and local elders for their support in the selection of informants, and Ambo District Agriculture Office for the provision of information regarding the number of veterinary clinics and animal health professionals in the district. Last but not least, the authors thank Dr. Tadesse Eguale (veterinarian at ALIPB, Addis Ababa University) for his assistance in translating local names of livestock ailments into their English equivalents, based on descriptions of symptoms and grouping the same into major disease groups. This research was financially supported by the Office of the Vice President for Research and Technology Transfer of Addis Ababa University.

\section{References}

[1] A. Belayneh, Z. Asfaw, S. Demissew, and F. Bussa, "Medicinal plants potential and use by pastoral and agro-pastoral communities in Erer Valley of Babile Woreda, Eastern Ethiopia," Journal of Ethnobiology and Ethnomedicine, vol. 8, pp. 12-16, 2012.

[2] A. Elizabeth, W. Hans, A. Zemede, and A. Tesfaye, "The current status of knowledge of herbal medicine and medicinal plants in Fiche, Ethiopia," Journal of Ethnobiology and Ethnomedicine, vol. 10, 2014.

[3] T. Lynam, W. De Jong, D. Sheil, T. Kusumanto, and K. Evans, "A review of tools for incorporating community knowledge, preferences, and values into decision making in natural resources management," Ecology and Society, vol. 12, p. 5, 2007.

[4] D. Abebe, "Traditional medicine in Ethiopia: the attempts being made to promote it for effective and better utilisation," SINET: Ethiopian Journal of Science, vol. 9, no. Suppl, pp. 61-69, 1986.

[5] M. Giday, Z. Asfaw, and Z. Woldu, "Medicinal plants of the Meinit ethnic group of Ethiopia: an ethnobotanical study," Journal of Ethnopharmacology, vol. 124, pp. 513-521, 2009.

[6] Z. Asfaw, "The role of home gardens in the production and conservation of medicinal plants," in Proceedings of Workshop on Biodiversity Conservation and Sustainable Use of Medicinal Plants in Ethiopia, pp. 76-91, Institute of Biodiversity Conservation and Research, Addis Ababa, Ethiopia, May 2001.

[7] Y. Yigezu, D. Berihun, and W. Yenet, "Ethnoveterinary medicines in four districts of Jimma zone, Ethiopia: cross sectional survey for plant species and mode of use," $B M C$ Veterinary Research, vol. 10, 2014. 
[8] T. Birhanu and D. Abera, "Survey of ethno-veterinary medicinal plants at selected Horro Gudurru districts, western Ethiopia," African Journal of Plant Science, vol. 9, pp. 185-192, 2015.

[9] G. Romha, T. A. Dejene, L. B. Telila, and D. F. Bekele, "Ethnoveterinary medicinal plants: preparation and application methods by traditional healers in selected districts of southern Ethiopia," Veterinary World, vol. 8, no. 5, pp. 674-684, 2015.

[10] C. Mohammed, D. Abera, M. Woyessa, and T. Birhanu, "Survey of ethno-veterinary medicinal plants in Melkabello district, Eastern Harerghe Zone, Eastern Ethiopia," Ethiopian Veterinary Journal, vol. 20, pp. 1-15, 2016.

[11] T. Fufa, M. Melaku, T. Bekele, T. Regassa, and N. Kassa, "Ethnobotanical study of ethnoveterinary plants in kelem Wollega zone, Oromia region, Ethiopia," Journal of Medicinal Plants Research, vol. 1, pp. 307-317, 2017.

[12] G. Kitata, D. Abdeta, and M. Amante, "Ethnoknowledge of plants used in veterinary practices in Midakegn district, west Showa of Oromia region, Ethiopia," Journal of Medicinal Plants Studies, vol. 5, pp. 282-288, 2017.

[13] F. Bekele, D. Lulu, D. Goshu, and R. Addisu, "Survey of ethnoveterinary medicinal plants at dale Sadi districts of Oromia Regional state, western Ethiopia," Journal of Natural Sciences Research, vol. 8, 2018.

[14] F. Tamiru, A. Dagmawit, G. Askale, S. Solomon, D. Morka, and T. Waktole, "Prevalence of ectoparasite infestation in chicken in and around Ambo town, Ethiopia," Iranian Journal of Veterinary Science and Technology, vol. 5, p. 4, 2014.

[15] B. Hunde, "Investigation of some engineering properties of soils found in ambo town, ethiopia," M.Sc thesis, Addis Ababa University, Addis Ababa, Ethopia, 2014.

[16] E. Zewdu, Y. Teshome, and A. Makwoya, "Bovine hydatidosis in Ambo municipality Abattoir, West Shoa, Ethiopia," Ethiopian Veterinary Journal, vol. 14, 2010.

[17] D. Bacha and E. Taboge, "Enset production in West Shewa Zone," Research Report No 49, EARO, Addis Ababa, Ethopia, 2003.

[18] M. Heinrich, A. Ankli, B. Frei, C. Weimann, and O. Sticher, "Medicinal plants in Mexico: healers' consensus and cultural importance," Social Science \& Medicine, vol. 47, no. 11, pp. 1859-1871, 1998.

[19] A. Andrade-Cetto and M. Heinrich, "From the field into the lab: useful approaches to selecting species based on local knowledge," Frontiers in Pharmacology, vol. 2, pp. 1-5, 2011.

[20] T. Lautenschläger, M. Monizi, M. Pedro et al., "First largescale ethnobotanical survey in the province of Uíge, northern Angola," Journal of Ethnobiology and Ethnomedicine, vol. 14, p. 51, 2018.

[21] B. Tadesse, G. Mulugeta, G. Fikadu, and A. Sultan, "Survey on ethno-veterinary medicinal plants in selected woredas of East Wollega zone, western Ethiopia," Journal of Biology, Agriculture and Healthcare, vol. 4, pp. 97-105, 2014.

[22] M. G. Gilbert, "Euphorbiaceae," in Flora of Ethiopia and Eritrea. Volume 2, Part 2: Canellaceae to Euphorbiaceae, S. Edwards, M. Tadesse, and I. Hedberg, Eds., pp. 265-380, The National Herbarium, Addis Ababa, Ethopia, 1995.

[23] O. Ryding, "Lamiaceae," in Flora of Ethiopia and Eritrea. Volume 5: Gentianaceae to Cyclocheilaceae, I. Hedberg, E. Kelbessa, S. Edwards, S. Demissew, and E. Persson, Eds., pp. 516-604, The National Herbarium, Addis Ababa, Ethopia, 2006.

[24] G. Yirga, M. Teferi, G. Brhane, and S. Amare, "Plants used in ethnoveterinary practices in Medebay-Zana district, Northern
Ethiopia," Journal of Medicinal Plants Research, vol. 6, pp. 433-438, 2012.

[25] A. Teklay, "Traditional medicinal plants for ethnoveterinary medicine used in kilte Awulaelo district, Tigray region, Northern Ethiopia," Advancement in Medicinal Plant Research, vol. 3, pp. 137-150, 2015.

[26] A. Usmane, T. Birhanu, M. Redwan, E. Sado, and D. Abera, "Survey of ethno-veterinary medicinal plants at selected districts of Harari Regional State, Eastern Ethiopia," Ethiopian Veterinary Journal, vol. 20, no. 1, pp. 1-22, 2016.

[27] E. Lulekal, Z. Asfaw, E. Kelbessa, and P. Van Damme, "Ethnoveterinary plants of Ankober district, North Shewa zone, Amhara region, Ethiopia," Journal of Ethnobiology and Ethnomedicine, vol. 10, no. 1, p. 21, 2014.

[28] M. Giday and T. Teklehaymanot, "Ethnobotanical study of plants used in management of livestock health problems by Afar people of Ada'ar District, Afar Regional State, Ethiopia," Journal of Ethnobiology and Ethnomedicine, vol. 9, no. 1, p. 8, 2013.

[29] T. Gedif and H.-J. Hahn, "The use of medicinal plants in selfcare in rural central Ethiopia," Journal of Ethnopharmacology, vol. 87, no. 2-3, pp. 155-161, 2003.

[30] E. Lulekal, Z. Asfaw, E. Kelbessa, and P. Van Damme, "Ethnomedicinal study of plants used for human ailments in Ankober district, North Shewa zone, Amhara region, Ethiopia," Journal of Ethnobiology and Ethnomedicine, vol. 9, no. 1, p. 63, 2013.

[31] T. Teklehaymanot, "Ethnobotanical study of knowledge and medicinal plants use by the people in Dek Island in Ethiopia," Journal of Ethnopharmacology, vol. 124, no. 1, pp. 69-78, 2009. 